\title{
A New General Approach to Quantify Nitrogen Fixation Exemplified for the Baltic Proper
}

\author{
Lars Håkanson*, Julia K. Hytteborn and Andreas C. Bryhn \\ Department of Earth Sciences, Uppsala University, Villav. 16, SE-752 36 Uppsala, Sweden
}

\begin{abstract}
This work uses empirical data from the HELCOM database and a new empirically-based model to predict the concentration of cyanobacteria in the Baltic Proper. The aim has been to estimate nitrogen fixation. The inherent variabilities/patchiness in the variables regulating nitrogen fixation are great. This means that different approaches may provide complementary information so that several relatively uncertain estimates may together provide less uncertainty in the estimate for nitrogen fixation in a given system. We show that there is marked variability in nitrogen fixation among different years (a factor of 20 between the year 2001 with the smallest value and 2005 with the highest value of about $900 \mathrm{kt} / \mathrm{yr}$ of N-fixation). The mean value for the period from 1997 to 2005 was $190 \mathrm{kt} / \mathrm{yr}$. TN/TP based on median monthly data has been higher than the Redfield ratio of 7.2 since 1994. $6.5 \%$ of all individual data $(\mathrm{n}=3001)$ from the surface-water layer $\left(44 \mathrm{~m}\right.$ ) in the Baltic Proper for samples with temperatures higher than $15^{\circ} \mathrm{C}$ (when risks of getting cyanobacteria blooms are favoured) have TN/TP lower than 7.2. The mean TN/TP is 20 for surface-water sites with temperatures higher than $15^{\circ} \mathrm{C}$, indicating that the average trophic conditions in the Baltic Proper are likely more limited by phosphorus than nitrogen. Nitrogen fixation is an important contributor to the nitrogen concentration and we give overall budgets for nitrogen and phosphorus in the Baltic Proper, including nutrient data from land uplift, which is the most important contributor for nutrients and often neglected in discussions about sources of nutrients to the Baltic Sea.
\end{abstract}

Keywords: Nitrogen fixation, cyanobacteria, phosphorus, nitrogen, salinity, temperature, marine systems, empirical model, Baltic Proper.

\section{INTRODUCTION}

Quantifying nitrogen fixation is essential for estimating the nitrogen balance in marine waters and understanding the causes of marine eutrophication. Since nitrogen fixation is triggered by high temperatures, low non-gaseous nitrogen concentrations and high phosphorus concentrations in the water, this process may determine which nutrient regulates primary production in the long run, and thus which nutrient should be abated in order to remediate marine eutrophication $[1,2]$.

Fig. (1) illustrates the main processes regulating external fluxes (atmospheric input and river inflow) of nutrients (nitrogen and phosphorus) to a given aquatic system, internal fluxes (sedimentation, resuspension, diffusion, denitrification and burial) including the very important relationship between the amount of the nutrient in dissolved (bioavailable) and particulate form (the only part that can settle out due to gravity) forms. The focus of this work is on nitrogen fixation.

Many papers discuss nitrogen fixation in the Baltic Sea [3-7]. Table 1 gives two empirical models for lakes as a background for this work. The first is the well-known OECD-model [8] predicting mean summer chlorophyll-a concentrations from total phosphorus concentrations (TP). This model yielded a coefficient of determination $\left(\mathrm{r}^{2}\right)$ of 0.77

*Address correspondence to this author at the Department of Earth Sciences, Uppsala University, Villav. 16, SE-752 36 Uppsala, Sweden;

E-mail: Lars.Hakanson@geo.uu.se when tested for lakes from a wide trophic level domain (characteristic TP-concenterations from $2.5 \mu \mathrm{g} / \mathrm{l}$, i.e., oligotrophic, to $100 \mu \mathrm{g} / \mathrm{l}$, i.e., hypertrophic). The second empirical model in Table 1 concerns the main topic of this work, a predictive model for cyanobacteria based on readily accessible $\mathrm{x}$-variables, such as the TP-concentration in this model (from [9]), which gave an $r^{2}$ of 0.71 when tested for 29 systems covering a very wide limnological domain (TP from 8 to $1300 \mu \mathrm{g} / \mathrm{l})$. Smith's empirical model for cyanobacteria applies to lakes.

The aim of this paper is to use a new empirically-based model from [10] to predict cyanobacteria and nitrogen fixation in the Baltic Proper. This model will be outlined in the next section.

Table 2 provides background for this work. This table summarizes transport processes to, within and from the Baltic Proper. The value (bolded) for nitrogen fixation is 130 000 tons per year. This value indicates an order-ofmagnitude figure for fixation in the Baltic Proper. The value is, however, very uncertain. References [11] and [12] gave values of $100 \mathrm{kt} / \mathrm{yr}$, [13] gave $130 \mathrm{kt} / \mathrm{yr}$ for the Baltic Proper and the Gulf of Finland, [14] estimated values from 18.2 to $186 \mathrm{kt} / \mathrm{yr}$ for the Baltic Proper and the Mecklenburg Bay and [4] noted a ranged of 30 to $260 \mathrm{kt} / \mathrm{yr}$ for the period 1992 to 1997. Yearly estimates of nitrogen fixation from the Baltic Proper are given in Table $\mathbf{3}$ (according to [5]). These values were calculated as increases in TN minus atmospheric deposition plus particulate $\mathrm{N}$ sedimentation at the Landsort Deep, and extrapolated to other basins according to local increases in TN. The summer increase in TN strongly coincided with blooms of N-fixing cyanobacteria in 1997 and 1998 and 


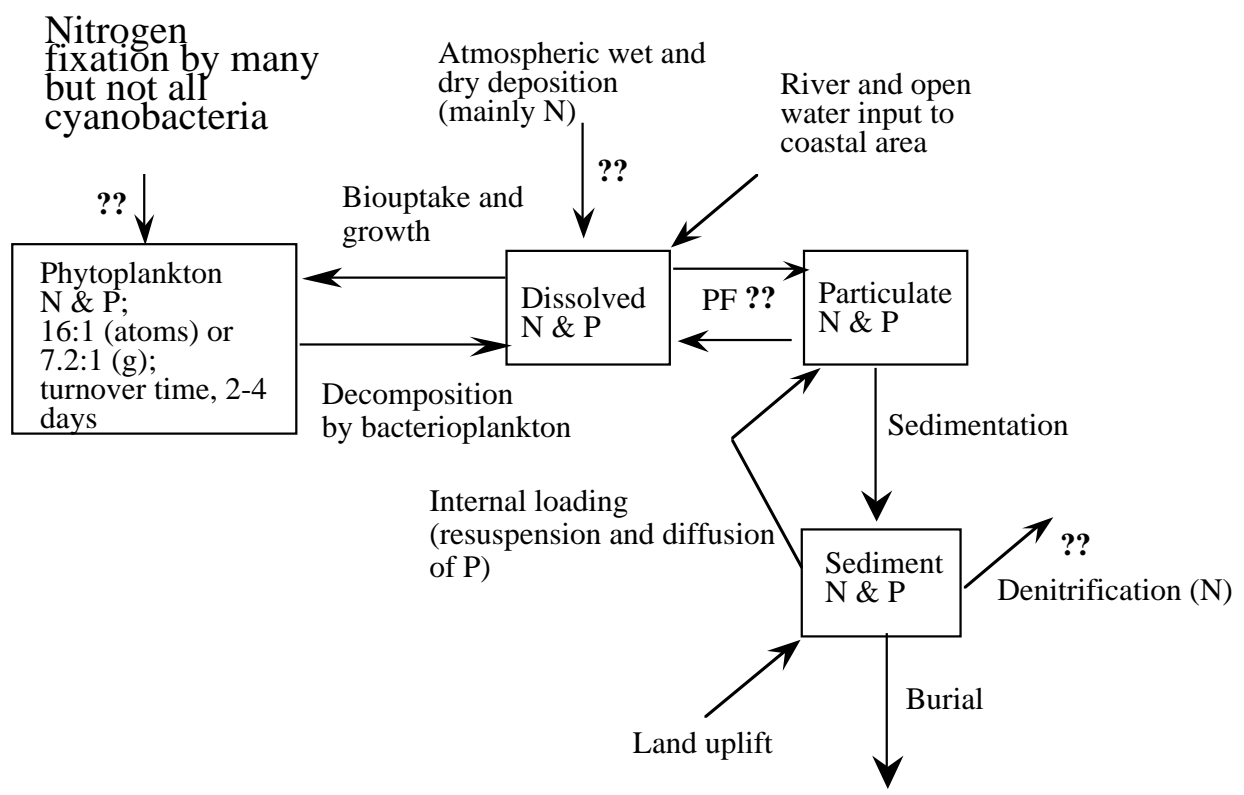

Fig. (1). Overview of important transport processes and mechanisms related to the concept of "limiting" nutrient. PF is the particulate fraction.

these values are about $60 \%$ of those calculated by [6]. [7] estimated the $\mathrm{N}$-fixation rate in the Baltic Proper to about a factor of 2 times the values in Table 3 (434 - $792 \mathrm{kt} / \mathrm{yr}$ ), while earlier estimates have generally been much lower and have not included night measurements, the complete growing season, or the important contribution from phytoplankton smaller than $10 \mu \mathrm{m}$.

Hence, all approaches to quantify the annual fluxes of nutrients in Fig. (1) are more or less uncertain. To quantify nitrogen fixation should be one of the most difficult and uncertain because the cyanobacteria show such very high coefficients of variation and this will be discussed in a following section.

Table 1. Regressions Illustrating the Key Role of Total Phosphorus (TP) in Predicting Chlorophyll-a (Chl, Summer Values) and the Biomass of Cyanobacteria (CB). $\mathbf{r}^{2}=$ Coefficient of Determination, $n=$ Number of Lakes Used in the Regression

\begin{tabular}{|c|c|c|c|c|c|c|}
\hline & Eq. & Range for TP & $\mathbf{r}^{2}$ & $\mathbf{n}$ & Units & Reference \\
\hline \hline Chl & $0.28 \cdot \mathrm{TP}^{0.96}$ & $2.5-100$ & 0.77 & 77 & $\mu \mathrm{g} / 1$ & {$[8]$} \\
\hline $\mathrm{CB}$ & $43 \cdot \mathrm{TP}^{0.98}$ & $8-1300$ & 0.71 & 29 & $\mu \mathrm{g} / 1$ & {$[9]$} \\
\hline
\end{tabular}

It is important to identify all major sources of nutrient inputs not just to the Baltic Proper but to all polluted water systems and to quantify all major fluxes because this will determine the expectation one would have on different, often costly, measures to reduce nutrient emissions and improve ecosystem conditions. If the total inflow of nitrogen to the Baltic Proper from countries/processes is 1800000 tons per year (Table 2), and if Swedish anthropogenic emissions are just $2.6 \%$ of all the nitrogen transport to the Baltic Proper, this will determine the expectations that one would have on such reductions, and also provide a possibility to compare the cost-effectiveness of alternative approaches to reduce nitrogen fluxes to the system.

The average composition of algae is given by the Redfield ratio 7.2, if the calculation is done in $g$ (see [15] and [16]) and $16: 1$, if the calculation is based on the number of atoms.

Another critical uncertainty in Fig. (1) concerns the equilibria between nutrients in dissolved and particulate phases, the time scales of these interactions, and what is actually meant by "limiting" nutrient. At short time scales (seconds to days), it is evident that the causal agent regulating/limiting biouptake and primary production is the concentration of the nutrient in bioavailable forms [17]. This also implies that the bioavailable forms are quickly regenerated so their supply is poorly described by their concentrations at any given sampling site [18]. This also explains why there are no practically useful predictive models for chlorophyll based on dissolved forms (DIN, DIP, phosphate, nitrate, etc.), but rather on TN or TP (see Table 1 or $[19,20]$ ). At longer time scales (weeks to years), and for all practical purposes in water management, one must recognize the difference between what is causally the "limiting" agent in primary production at short time scales, and what is the form of the nutrient limiting predictions of chlorophyll or cyanobacteria at the ecosystem scale for longer periods of time. This paper uses an empirical model for total cyanobacteria, which concerns the latter aspects, the ecosystem scale (the entire Baltic Proper) using monthly data.

The problem to understand and predict $\mathrm{TN}$-concentrations in marine systems is accentuated by the fact that there are no (to the best of our knowledge) practically useful models to quantify the particulate N-fraction in saltwater systems (but such approaches are available for phosphorus in lakes and brackish systems, see [21]. In mass-balance modelling, it is imperative to have a reliable algorithm for particulate nitrogen, since the particulate fraction $(\mathrm{PF})$ is the only fraction that by definition can settle out due to gravity. 
Table 2. Background Budget on the Transport of Nitrogen and Phosphorus to and from the Baltic Proper (t/yr); from [48]. The Data from the Swedish Environmental Protection Agency (SNV [49]) Concern Mean Values for the period 1982 and 1989; Data from HELCOM [43] is for 2000

\begin{tabular}{|c|c|c|c|c|c|c|}
\hline Sweden & 44300 & 46636 & & 1780 & 1219 & \\
\hline Baltic states & 72600 & 145697 & & 1890 & 5408 & \\
\hline Russia & - & 90229 & & - & 5863 & \\
\hline Poland & 109900 & 191521 & & 19100 & 12698 & \\
\hline Germany & 20000 & 20602 & & 2750 & 512 & \\
\hline Denmark & 51000 & 27664 & & 7860 & 1193 & \\
\hline Precipitation & 289900 & 192400 & & 3420 & - & \\
\hline Nitrogen fixation & 130000 & - & - & - & & \\
\hline Land uplift & & & 480000 & & & 160000 \\
\hline Inflow from Kattegat & & & 120000 & & & 14000 \\
\hline Inflow from Bothnian Sea & & & 340000 & & & 14000 \\
\hline Sum from processes: & & & $1261000-1359000$ & & & 191420 \\
\hline Order-of-magnitude value: & & & $\approx 1300000$ & & & $\approx 190000$ \\
\hline Total inflow $(\mathrm{A}+\mathrm{B})$ : & & & $\approx 1800000$ & & & 220000 \\
\hline Burial in sediments & & \multicolumn{2}{|c|}{$(3 \cdot 180000)^{*}=540000$} & \multicolumn{3}{|c|}{$(220000-40000)=180000$} \\
\hline Denitrification & \multicolumn{3}{|c|}{$(1800000-600000-540000)=660000$} & & & \\
\hline
\end{tabular}

* The nitrogen concentration is set to be 3 times higher than the phosphorus concentration in these sediments. H\&L = [48]. The role of land uplift and the task of finding the most cost-efficient remedial strategy for the Baltic Sea are discussed in more detail in [55].

From previous modelling work [22], one can conclude that it is also very difficult to quantify denitrification (Fig. 1). Denitrification depends on sediment red-ox conditions, i.e., on sedimentation of degradable organic matter and the oxygen concentration in the deep-water zone, but also on the frequency of resuspension events, on the presence of mucusbinding bacteria, and on zoobenthos and bioturbation. Given this complexity, it is easy to understand why empirically well-tested algorithms to quantify denitrification on a monthly basis do not exist to the best of our knowledge. The atmospheric wet and dry deposition of nitrogen may (as indicated in Fig. 1) be very large (in the same order as the tributary inflow) and patchy [23], which means that for large coastal areas and smaller systems distant from measurement stations, the uncertainty in the magnitude of atmospheric wet and dry $\mathrm{N}$-deposition is also generally very large.

Table 3. Yearly N-Fixation (kt/yr) in the Baltic Proper Based on Data from [5]

\begin{tabular}{|c|c|c|}
\hline Year & Minimum & Maximum \\
\hline \hline 1994 & 290 & 350 \\
\hline 1995 & 360 & 420 \\
\hline 1996 & 180 & 250 \\
\hline 1997 & 340 & 430 \\
\hline 1998 & 180 & 330 \\
\hline
\end{tabular}


The question about "limiting" nutrient is central in aquatic ecology and has been treated in numerous papers $[19,20,23-26]$. The salinity is of paramount importance to the predictions of chlorophyll and cyanobacteria. The salinity influences the aggregation of suspended particles [21], of particular interest in understanding variations in water clarity, which in turn regulate the depth of the photic zone and hence primary production. The saltier the water, the greater the flocculation of suspended particles. An increased salinity together with N-limitation and increased light seem to control factors of $\mathrm{N}$-fixing cyanobacteria in estuaries, according to [27].

The abundance of cyanobacteria compared to other algal groups is closely related to the TN/TP-ratio. Cyanobacteria have been found to dominate lake primary production at
TN/TP $\leq 29$ (by weight) and are much less abundant at higher ratios, while nitrogen-fixing cyanobacteria tend to dominate at TN/TP $\leq 22$ [28]. [9] found TP to be a better predictor of the biomass of cyanobacteria $(\mathrm{CB})$ than $\mathrm{TN}$ and $\mathrm{TN} / \mathrm{TP}$.

\section{THE MODEL}

This approach does not concern cyanobacteria produced in the benthic zone. In the derivation of the model [10], data from many databases were used, and Table $\mathbf{4}$ gives a compilation of information used as well as data used for the Baltic Proper (from the HELCOM data base). Fig. (2A) gives the (log-log) regression between chlorophyll-a concentrations and total cyanobacteria $(\mathrm{CB}=$ median values for the growing season) using lake data. One can note a highly significant and mechanistically understandable strong positive co-

Table 4. Compilation of Main References (A), Data and Statistics (B) for the General, Comprehensive Data Base. Note that All Data Used in this Data Base Represent Median Surface Water Values for the Growing Season, and (C) Data from HELCOM (http://www.ices.dk/ocean/asp/helcom/helcom.asp?Mode=1) Used in this Work for Water Temperature, Salinity, Total-N and Total-P from the Entire Baltic Proper Between 1990 and 2005 and Chlorophyll-a Data from 1974 to 2005

\begin{tabular}{|c|c|c|c|}
\hline A. Area & Country & Salinity Range & Main References \\
\hline \hline Chesapeake Bay & U.S.A. & $<2-35$ & http://www.chesapeakebay.net/data/wq_query1.cfm?db=CBP_WQDB \\
\hline Italian coast & Italy & $15-40$ & http://dataservice.eea.europa.eu/dataservice/metadetails.asp?id=836 \\
\hline Crimean lakes & Ukraine & $25-275$ & [51] \\
\hline Baltic Sea & Sweden & $2.4-5.5$ & Magnus Karlsson, Å, pers. comm. \\
\hline Bothnian Bay & Sweden & $0.3-1.5$ & http://dataservice.eea.europa.eu/dataservice/metadetails.asp?id=836 \\
\hline West coast & Sweden, Norway & $6.4-27$ & http://dataservice.eea.europa.eu/dataservice/metadetails.asp?id=836 \\
\hline Swedish lakes & Sweden & 0 & http://info1.ma.slu.se/db.html \\
\hline Baltic coast & Sweden, Finland & $5-7.5$ & [20, 52] \\
\hline Lakes, shelf, marine & Several & $0-36$ & {$[25,50]$} \\
\hline Ringkobing Fjord & Denmark & $3.9-14.5$ & [53, 54] \\
\hline
\end{tabular}

\begin{tabular}{|c|c|c|c|c|}
\hline Mean (MV) & 533 & 40.5 & 7.9 & 15.9 \\
\hline Minimum & 1 & $<1$ & 0.12 & 0 \\
\hline Maximum & 2110 & 1090 & 60.3 & 275 \\
\hline Number of data (n) & 658 & 582 & 709 & 714 \\
\hline
\end{tabular}

\begin{tabular}{|c|c|c|c|c|c|}
\hline C. & Temp $\left.{ }^{\circ} \mathbf{C}\right)$ & Salinity & Total-N $(\boldsymbol{\mu g} / \mathbf{l})$ & Total-P $(\boldsymbol{\mu g} / \mathbf{l})$ & $\mathbf{C h l - a}(\boldsymbol{\mu g} / \mathbf{l})$ \\
\hline \hline Min & -0.71 & 1.29 & 7.0 & 0.3 & 0.1 \\
\hline Max & 24.02 & 24.89 & 2493 & 780.6 & 71.6 \\
\hline Mean (MV) & 6.44 & 8.41 & 298.1 & 44.83 & 2.11 \\
\hline Median (M50) & 4.96 & 7.40 & 291.4 & 25.71 & 1.70 \\
\hline Standard dev. (SD) & 4.27 & 2.33 & 78.39 & 41.93 & 2.23 \\
\hline Coeff. of var. (CV) & 0.66 & 0.28 & 0.26 & 0.94 & 1.06 \\
\hline Number of data (n) & 43125 & 43502 & 41690 & 44152 & 14384 \\
\hline
\end{tabular}



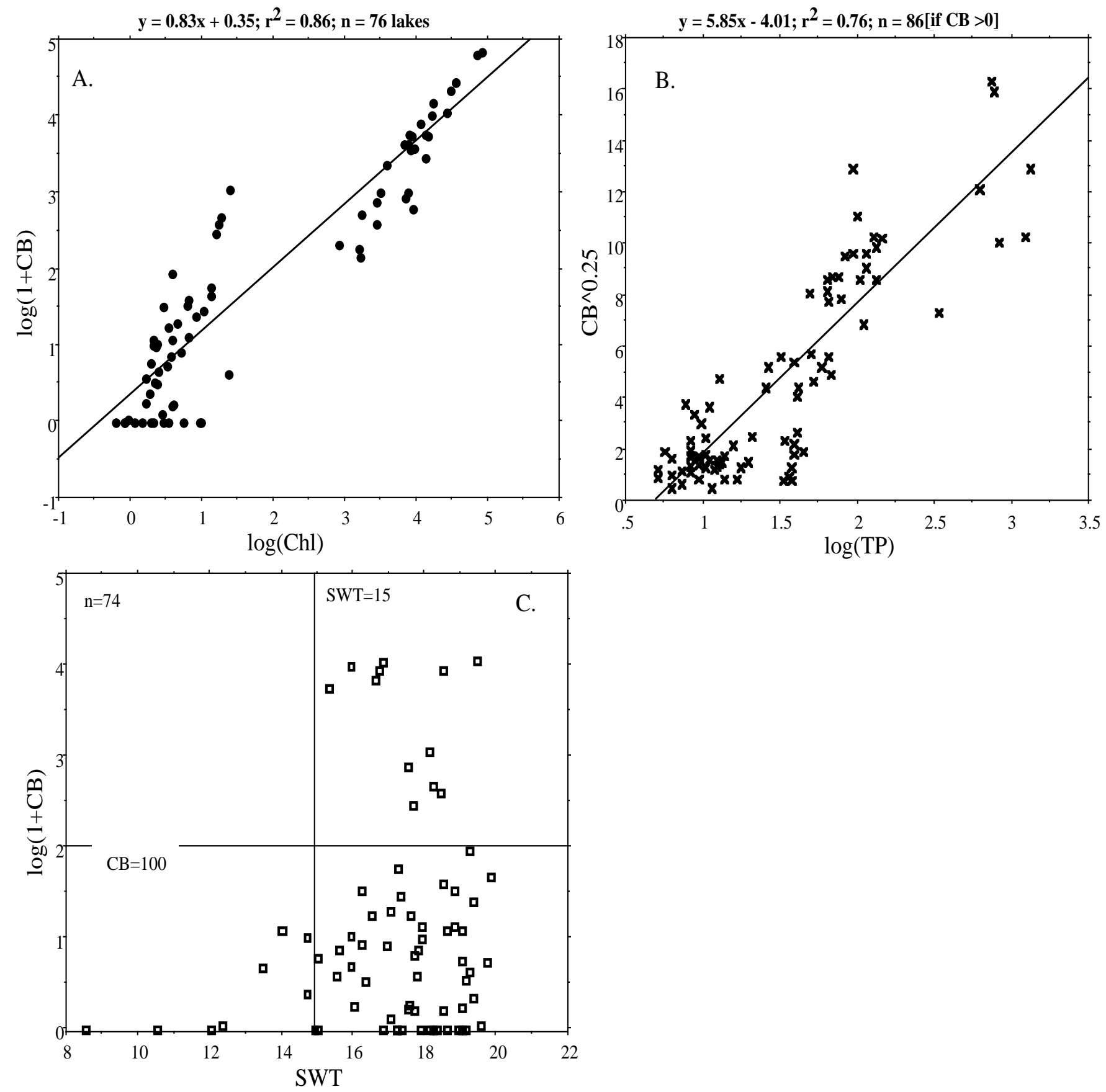

Fig. (2). (A) Regression between $\log (1+\mathrm{CB})$ and $\log (\mathrm{Chl})$ based on data from 76 lakes. The figure also gives the coefficients of determination $\left(\mathrm{r}^{2}\right)$ and the regression lines. Cyanobacteria (CB) in $\mu \mathrm{g} w \mathrm{w} / \mathrm{l}(\mathrm{ww}=$ wet weight), chlorophyll-a concentrations $(\mathrm{Chl})$ in $\mu \mathrm{g} / \mathrm{l}$. $(\mathbf{B}) \mathrm{Regres}-$ sion between $\mathrm{CB}$ (transformed into $\mathrm{CB}^{0.25}$; $\mathrm{CB}$ in $\mu \mathrm{g}$ ww/l) and $\log (\mathrm{TP})(\mathrm{TP}$ in $\mu \mathrm{g} / \mathrm{l}$ ) using median values for the growing season from 86 systems with CB-values higher than zero. (C) Scatter plot between cyanobacteria (transformed into $\log (1+\mathrm{CB})$; CB in $\mu \mathrm{g}$ ww/l) versus surface water temperatures (SWT in ${ }^{\circ} \mathrm{C}$ ) based on data from 74 systems. From [10].

variation between these two measures of primary production in lake water. This relationship might have looked different had it been based on daily, weekly or monthly values and it is probable that this co-variation also exists for many marine systems. The following calculations first show maximum values for nitrogen fixation.

In a following section, we will also discuss the fraction of $\mathrm{N}$-fixing species of the total biomass of cyanobacteria in the Baltic Proper.

\section{CB Versus TP}

The basic regression is given in Fig. $(\mathbf{2 B})\left(\mathrm{r}^{2}=0.76 ; \mathrm{n}=\right.$ 86). This regression includes data from more systems than the equation given by [9] and it also yields a higher $\mathrm{r}^{2}$-value (0.76 as compared to 0.71 ).

\section{CB Versus Temperature}

In the literature, temperatures between 15 and $17^{\circ} \mathrm{C}$ have been reported as the minimum for cyanobacteria blooms in 
Model for cyanobacteria

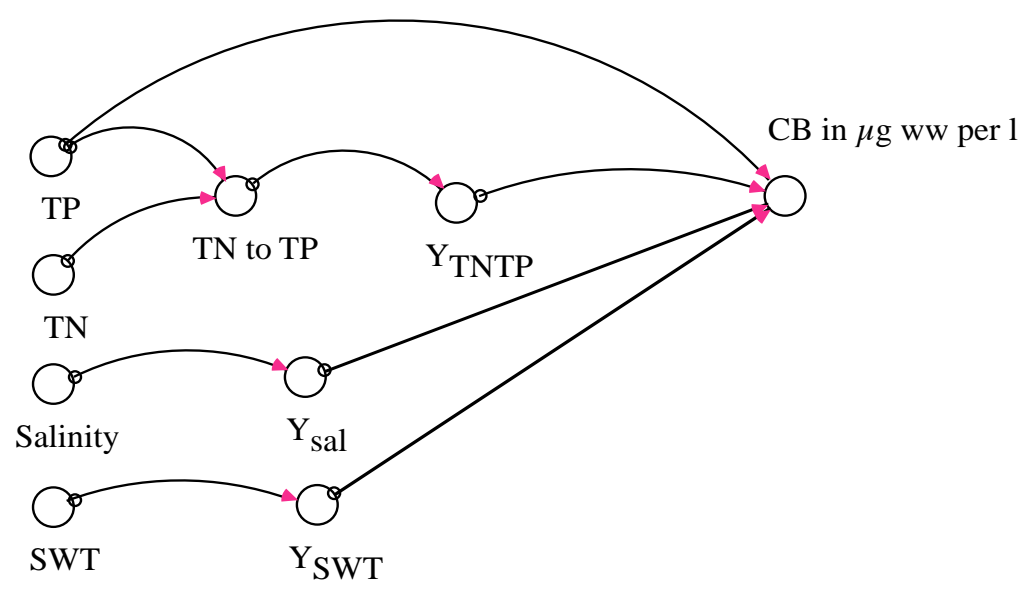

$\mathrm{CB}=\left((5.85 \cdot \log (\mathrm{TP})-4.01)^{4}\right) \cdot \mathrm{Y}_{\mathrm{TNTP}} \cdot \mathrm{Y}_{\mathrm{SWT}} \cdot \mathrm{Y}_{\mathrm{Sal}}$

$\mathrm{CB}$ in $\mu \mathrm{g} \mathrm{ww} / \mathrm{l}$

Salinity in psu

$\mathrm{SWT}=$ Surface water temperature in ${ }^{\circ} \mathrm{C}$

Total-N (TN) in $\mu \mathrm{g} / 1$

Total-P(TP) in $\mu \mathrm{g} / 1$

$\mathrm{Y}_{\mathrm{TNTP}}=$ if TN/TP $<15$ then $(1-3 \cdot(\mathrm{TN} / \mathrm{TP} / 15-1))$ else 1

$\mathrm{Y}_{\mathrm{SWT}}=$ if SWT $\geq 15$ then $\left(0.86+0.63 \cdot\left((\mathrm{SWT} / 15)^{\wedge} 1.5-1\right)\right)$ else $\left(1+1 \cdot\left((\mathrm{SWT} / 15)^{\wedge} 3-1\right)\right)$

$\mathrm{Y}_{\mathrm{sal}}=$ if salinity $<10$ then $\left(2.1+1.1 \cdot\left((\right.\right.$ salinity/10)^2-1) $)$ else $\left(2.1-115 \cdot\left((\text { salinity/10 })^{\wedge} 0.01-1\right)\right)$

Model domain: $4<\mathrm{TP}<1300 ; 165<\mathrm{TN}<6830 ; 0<$ salinity $<40 ; 8<$ SWT $<25$

Fig. (3). Outline of the model to predict median summer values of cyanobacteria in lakes and coastal areas (from [10]).

freshwater systems and in the Baltic Sea [7, 29, 30]. Laboratory experiments on cyanobacteria also support this conclusion [31-33]. There are also reports that cyanobacteria have a requirement of temperatures of about $20-21{ }^{\circ} \mathrm{C}$ to form blooms. Those reports are from a freshwater lake in Canada [34], the North Pacific Ocean [35] and an estuary in Australia [36]. The optimal growth temperatures in laboratory experiments are usually around $25^{\circ} \mathrm{C}$ for many species $[31,33$, 37], but these experiments often use species from temperate areas. With higher temperatures, growth rate usually starts to decrease. In field data from the Baltic Sea [3], this decrease in growth rate is not shown because there are few occasions with temperatures higher than $20^{\circ} \mathrm{C}$.

Fig. (2C) gives data on the relationship between $\mathrm{CB}$ $(\log (1+\mathrm{CB}))$ and surface water temperatures (SWT in ${ }^{\circ} \mathrm{C}$ ) from 74 systems. One can note that all systems with $\mathrm{CB}$ exceeding $100 \mu \mathrm{g} / \mathrm{l}$ (median values for the growing season) have temperatures higher than $15^{\circ} \mathrm{C}$. Fig. (3) gives a compilation of the model. The dimensionless moderator for temperature influences on $\mathrm{CB}\left(\mathrm{Y}_{\mathrm{SWT}}\right)$ is given by:

If $\mathrm{SWT} \geq 15^{\circ} \mathrm{C}$, then

$\mathrm{Y}_{\mathrm{SWT}}=(15 / 17.5) \cdot\left(1+0.63 \cdot\left((\mathrm{SWT} / 15)^{1.5}-1\right)\right)$ else

$\mathrm{Y}_{\mathrm{SWT}}=\left(1+1 \cdot\left((\mathrm{SWT} / 15)^{3}-1\right)\right)$

This means that if SWT $=15^{\circ} \mathrm{C}, \mathrm{Y}_{\mathrm{SWT}}=0.86$; if SWT $=$ $17.5, \mathrm{Y}_{\mathrm{SWT}}=1$; if $\mathrm{SWT}=25, \mathrm{Y}_{\mathrm{SWT}}=1.48$, etc. So, when the temperature is $25^{\circ} \mathrm{C}$, the risks of getting high concentrations of cyanobacteria a factor of 1.48 higher than at $17.5^{\circ} \mathrm{C}$, if all else is constant.

\section{CB Versus Salinity}

In hypertrophic lakes, the biomass of cyanobacteria can be very high with concentrations of about $100 \mathrm{mg} / \mathrm{l}$ [9]. [38, 39] found no data on $\mathrm{N}$-fixing planktonic species in estuaries and coastal seas, except for the Baltic Sea and the PeelHarvey estuary, Australia. Also results from [40] support this general absence of $\mathrm{N}$-fixing cyanobacteria in estuaries. There are more than 10 nitrogen fixing cyanobacteria species in the Baltic Proper [6]. The number of species and the nitrogen fixation rates have been considerably revised upwards during recent years [7]. A field study in the Baltic Sea [3] indicates that in this brackish environment species of cyanobacteria have, interestingly, the highest biomass at salinities of $7-8$ psu and that the blooms in Kattegat and Belt Sea are more frequent if the salinity is below $11.5 \mathrm{psu}$. Results from a laboratory experiment with cyanobacteria from the Baltic Sea support the highest growth rates at salinities between 5 and 10 psu [33]. According to [41], blooms of cyanobacteria in marine environments may not be as common as in freshwater systems. In marine systems, there are just a few dominant genera. In a field study in the Pacific Ocean [35], there was no correlation between the salinity and the abundance of cyanobacteria and no cyanobacteria were found in the cooler, less saline waters. In this model (Eq. 2), the influences of the 
salinity on cyanobacteria are motivated by empirical data from many systems [10]:

If the salinity $<10 \mathrm{psu}$, then

$\mathrm{Y}_{\text {sal }}=\left(2.1+1.1 \cdot\left((\text { salinity } / 10)^{2}-1\right)\right)$, else

$Y_{\text {sal }}=\left(2.1-115 \cdot\left((\text { salinity/10 })^{0.01}-1\right)\right)$

This means that at a salinity of $10 \mathrm{psu}, \mathrm{Y}_{\mathrm{sal}}$ is 2.1 and $\mathrm{CB}$ a likely factors of 2.1 higher than in freshwater systems.

\section{CB Versus TN/TP}

Fig. (4A) shows a scatter plot between $\log (\mathrm{CB})$ and TN/TP. High CB-values only appear in systems with relatively low TN/TP. The regression between $\log (\mathrm{CB})$ and TN/TP attains a maximum value $\left(\mathrm{r}^{2}=0.73\right.$; $\log (\mathrm{CB})=0.142 \cdot \mathrm{TN} / \mathrm{TP}+5.47 ; \mathrm{n}=61)$ if only data from systems with TN/TP smaller than 40 are used. The upper curve (circles) in Fig. (4B) gives the $r^{2}$-values when only systems with TN/TP smaller than $10,15,20, \ldots .100$, respectively, were used in the regressions. The lower curve in Fig. (4B) gives similar results when only systems with higher TN/TP were used. Note that there is no statistically significant $(\mathrm{p}<0.01)$ relationship between $\log (\mathrm{CB})$ and TN/TP if TN/TP is higher than 15 .

The basic regression between $\mathrm{CB}$ and TP given by Eq. 1 is complemented with a dimensionless moderator related to $\mathrm{TN} / \mathrm{TP}, \mathrm{Y}_{\mathrm{TNTP}}$, defined by:

If TN/TP $<15$ then $\mathrm{Y}_{\mathrm{TNTP}}=(1-3 \cdot((\mathrm{TN} / \mathrm{TP}) / 15-1))$ else $\mathrm{Y}_{\mathrm{TNTP}}$ $=1$

This means that for systems with TN/TP (based on median values for the growing season) higher than 15 , one can use the basic regression without any correction, but for systems with TN/TP $<15$, Eq. 3 is used. If, e.g., TN/TP = 7.2, then $\mathrm{Y}_{\mathrm{TNTP}}=2.56$, and the CB-value a factor of 2.56 higher than the value suggested by the basic regression.

The general model for cyanobacteria may give rather uncertain predictions for systems with high TN/TP and low temperatures. However, during such conditions, the $\mathrm{N}$ fixation should be small. Predicting conditions with high $\mathrm{CB}$ is evidently more important in calculations of $\mathrm{N}$-fixation. Due to the fact that all methods to estimate $\mathrm{N}$-fixation in entire systems at longer time scales (such as month or years) are very uncertain, there is good reason to regard the approach presented here as complementary to other approaches.

Measured N-fixation tends to follow a similar pattern as the prevalence of cyanobacteria [6, 38, 39]. Analyses using gene sequencing techniques have suggested that more organisms than we currently know may fix nitrogen in both lakes and marine systems [42].

\section{DATA AND DATA UNCERTAINTY}

To estimate the $\mathrm{N}$-fixation in the Baltic Proper, we have used one main dataset, the HELCOM data compiled in Table 4C [43]. All calculations have used median monthly values on TN, TP, salinity and temperature since these are the obligatory driving variables in the model.

The uncertainty in the model variables may be expressed by the coefficient of variation $(\mathrm{CV}=\mathrm{SD} / \mathrm{MV} ; \mathrm{SD}=$ standard deviation; $\mathrm{MV}=$ the mean value) and Table $\mathbf{5}$ gives a compi- lation of characteristic CV-values for many of the variables discussed in this work for 58 lakes. One should note from Table 5 that cyanobacteria should be expected to have significantly higher CVs than most other variables and are therefore more difficult to predict with a high certainty. It is also important to note that dissolved inorganic nutrient fractions have considerably higher CVs than TN and TP. Thus, dissolved inorganic nutrient fractions are, in relation to $\mathrm{TN}$ and TP, not only poorly correlated with chlorophyll and Secchi depth [44], but given their high inherent uncertainties, it is much more costly to determine reliable mean/median values that can be used in ecosystem models, whose scientific quality and usefulness is given by their predictive power.

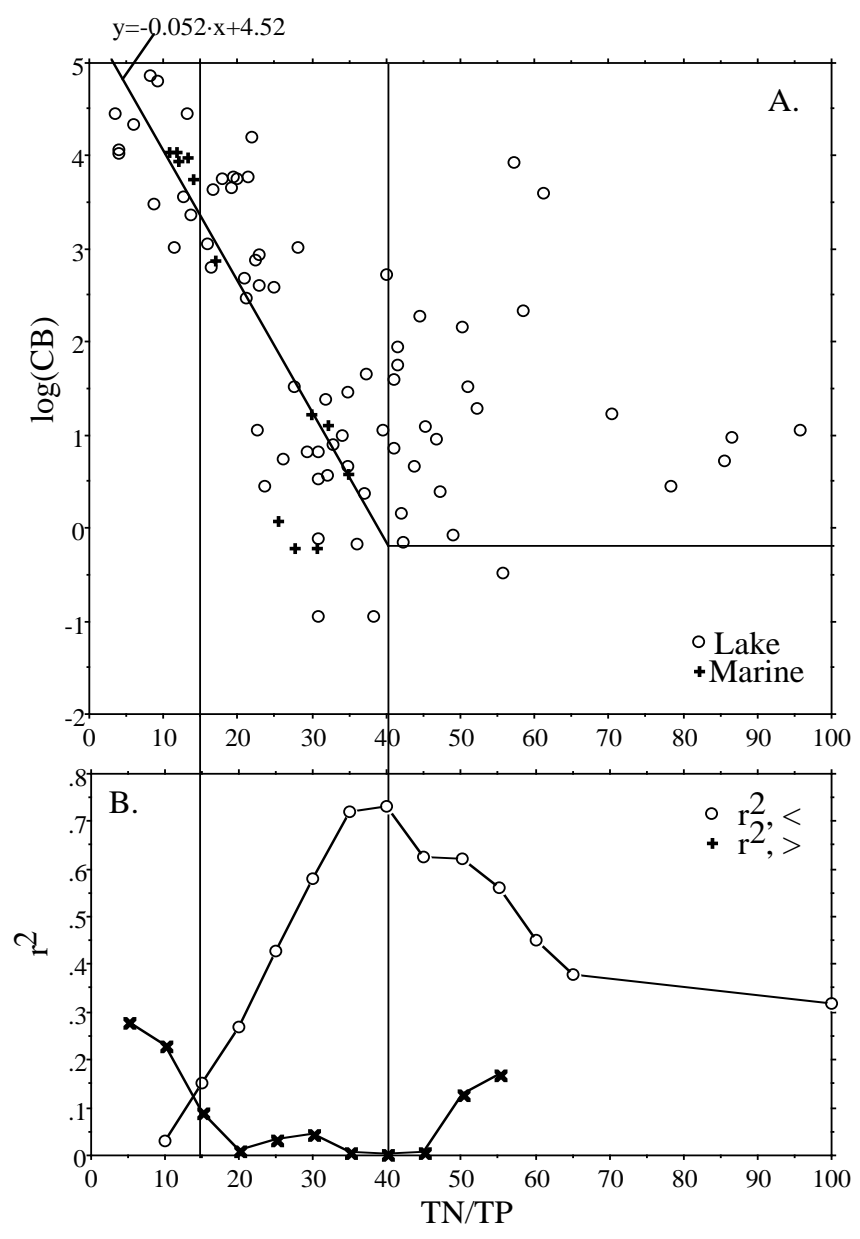

Fig. (4). (A) Scatter plot between $\log (\mathrm{CB})$ and TN/TP. The regression line is based on data from systems where TN/TP $<15$. (B) Compilation of $\mathrm{r}^{2}$-values between $\log (\mathrm{CB})$ and TN/TP using data from systems when successively smaller $(<)$ and higher $(>)$ TN/TP have been omitted. The maximum $r^{2}$ is obtained for systems with TN/TP < 40; very low $r^{2}$-values are obtained if the regressions are done for systems with TN/TP $>15$ (from [10]).

The basic factors regulating $\mathrm{CV}$ s for chlorophyll and cyanobacteria (i.e., nutrients, temperature, light, salinity, predation, analytical uncertainties related to sampling) should be similar in most aquatic systems. [45] showed that for the River Danube, the CV for the cyanobacteria was, on average, a factor of 1.3 higher than for chlorophyll.

This means that one should expect that the $r^{2}$-value one can hope to achieve would be lower for cyanobacteria than 
for chlorophyll and this is also the information conveyed in Table 1 ( $\mathrm{r}^{2}=0.71$ and 0.77 , respectively).

Table 5. Coefficients of Variation (CV) for Twelve Water Variables Based on Data from 58 Swedish Lakes (from [10]). The Values Describe Conditions During the Growing Season and are Typically Based on 66 Measurements and in No Case Less than 6

\begin{tabular}{|c|c|c|c|}
\hline Variable & Median & Min & Max \\
\hline \hline Cyanobacteria & 1.76 & 0.64 & 3.91 \\
\hline Ammonium & 0.74 & 0.42 & 3.91 \\
\hline Nitrate + nitrite & 0.73 & 0.09 & 2.78 \\
\hline Total algal biomass & 0.68 & 0.34 & 1.83 \\
\hline Phosphate & 0.58 & 0.24 & 1.14 \\
\hline Chlorophyll & 0.43 & 0.25 & 1.29 \\
\hline Total-P & 0.37 & 0.23 & 0.78 \\
\hline Total-N & 0.24 & 0.04 & 0.72 \\
\hline Secchi depth & 0.21 & 0.11 & 0.51 \\
\hline Temperature & 0.14 & 0.10 & 0.37 \\
\hline Calcium & 0.11 & 0.03 & 0.83 \\
\hline pH & 0.04 & 0.01 & 0.09 \\
\hline
\end{tabular}

\section{RESULTS}

\section{Calculating Maximum Nitrogen Fixation in the Baltic Proper}

Table $\mathbf{6}$ exemplifies the calculation routine using data for 2004. The table gives the median monthly values for surfacewater temperatures (i.e., for samples taken above the theoretical wave base of $44 \mathrm{~m}$ in the Baltic Proper; see [46]), salinity, TN, TP and TN/TP, as well as the dimensionless moderators for salinity $\left(\mathrm{Y}_{\text {sal }}\right)$, surface-water temperature $\left(\mathrm{Y}_{\mathrm{SWT}}\right)$ and TN/TP $\left(\mathrm{Y}_{\mathrm{TNTP}}\right)$. The calculated monthly concentrations of total cyanobacteria (CB in $\mu \mathrm{g} / \mathrm{l}$ ) are given as well as the calculated maximum potential $\mathrm{N}$-fixation. The table also shows the dimensional adjustments used in the calculation. From Table 6, one can note:

- The maximum potential $\mathrm{N}$-fixation (in 2004) in the Baltic Proper was about $255 \mathrm{kt}$, with highest values in July, August and September.

- This corresponds very well to the overall values given in Table 3.

The calculated lowest and highest values for the maximum potential annual $\mathrm{N}$-fixation in the Baltic Proper for the period 1997 to 2005 are given in Table 7. One can note:

- The variation among the years is very high: the smallest value is $45 \mathrm{kt}$, the highest $908 \mathrm{kt}$.

- The average annual value is $191 \mathrm{kt}$.

Both [5] and [6] measured higher rates in 1997 than in 1998, but our results show higher rates in 1998 (58 and 71 $\mathrm{kt}$, respectively). However, the order-of-magnitude is about the same in our measurements for these two years, and the uncertainty in the calculated values is higher than the difference between these two years.

Fig. (5) illustrates the modelled monthly concentrations of cyanobacteria from 1996 to 2005 . One can see clear seasonal patterns and that the modelled values are very high for 2005 , which also had a very high and much discussed algal bloom.

Using the model, one can also clarify the factors contributing to the calculated values. Fig. (6) illustrates predictions if the four $\mathrm{x}$-variables (i.e., the monthly median values of temperature, salinity, TN and TP) were reduced by $25 \%$. A reduction in $\mathrm{TN}$ would increase the predicted biomass of total cyanobacteria considerably, while reductions in salinity, temperature and TP would lower the predicted values; the clearest response would be from reductions in temperature. According to our results, the high CB-values in 2005 may be attributed to relatively high TP-concentrations and high temperatures in the summer and fall.

\section{TN/TP and Cyanobacteria}

If TN/TP is lower than 7.2, phytoplankton species that can take up dissolved nitrogen of atmospheric origin will be favoured. Empirical data in Fig. (4) show that there is a threshold limit for the ratio not at 7.2 but rather at 15. Fig. (7) gives a scatter plot of all available data on TN/TP $(\mathrm{n}=$ 24048) from the surface-water layer in the Baltic Proper from 1990 to 2005; Fig. (8) shows variations in median monthly TN/TP in relation to the Redfield ratio of 7.2 and the threshold ratio of 15 . From these two figures, one can note that there are no major changes in the general temporal trend. There is also a very large scatter in the data and clear seasonal patterns.

Table 8 gives a compilation of TN/TP statistics for the Baltic Proper, divided into four categories: (1) all data from the surface-water layer, (2) all data for situations with temperatures higher than $15{ }^{\circ} \mathrm{C}$, (3) all data with Temp $>15{ }^{\circ} \mathrm{C}$ and from water depths $\langle 20 \mathrm{~m}$, and (4) all data with Temp > $15^{\circ} \mathrm{C}$, water depths $<20 \mathrm{~m}$ and $\mathrm{TP}>10 \mu \mathrm{g} / \mathrm{l}$. This table also gives information on the percentage of the data with TN/TP smaller than 7.2 and smaller than 15 . The main conclusion from this table is that less than $7 \%$ of the values are smaller than 7.2 and that between 30 and 50\% of the TN/TP-ratios are smaller than 15. Fig. (9) gives a frequency distribution for the data at sites with temperatures higher than $15^{\circ} \mathrm{C}$.

The key information in Figs. (7-9) and Table 8 is that the conditions in the surface-water layer of the Baltic Proper often favour cyanobacteria. However, in more than $70 \%$ of the situations when the water temperature is higher than 15 ${ }^{\circ} \mathrm{C}$ and the risks of blooms of cyanobacteria are highest, the system is not $\mathrm{N}$-limited but P-limited (Fig. 9). To minimize the overall primary phytoplankton production in the Baltic Proper (eutrophication), one should mainly reduce the discharges of phosphorus to the systems. To achieve a goal of less eutrophication in the Baltic Proper, N-reductions would be more or less meaningless, which is well in line with results presented by [1]. In $30 \%$ of the situations, when TN/TP is lower than 15 , reductions in $\mathrm{N}$ would favour nitrogen fixing cyanobacteria, which should be avoided.

Fig. (10) gives a regression between median monthly concentrations of chlorophyll-a and modelled concentrations 
Table 6. Calculation of Monthly and Annual Maximum Potential Nitrogen Fixation in the Baltic Proper Using Data from 2004

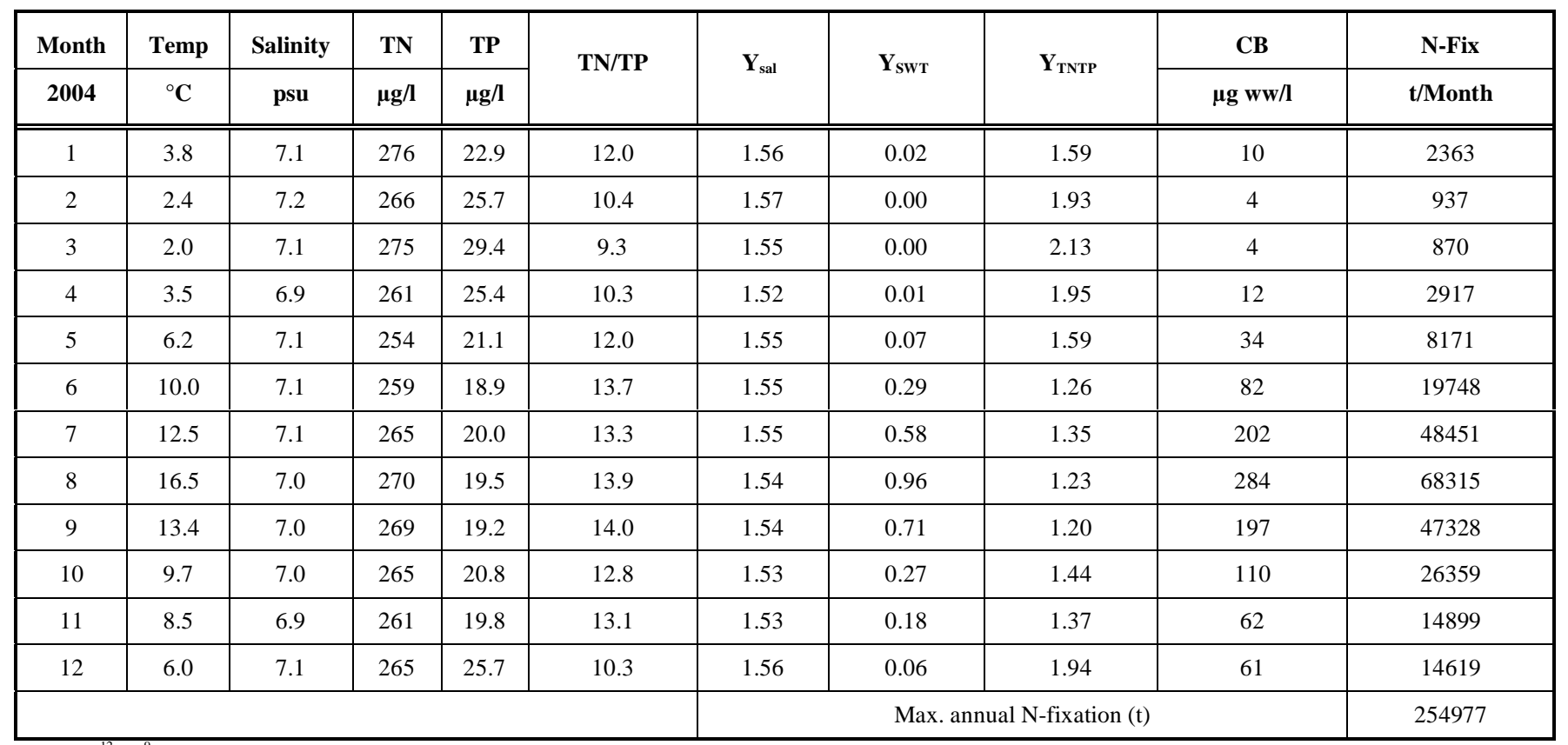

of total cyanobacteria. The co-variation is significant ( $\mathrm{p}=0.0008)$, but the scatter around the regression line is considerable $\left(r^{2}=0.11\right)$. Two reasons for this low $r^{2}$-value is that the range in the monthly chlorophyll data is relatively small in the Baltic Proper (from 0.2 to $4 \mu \mathrm{g} / \mathrm{l}$ ), and that the $\mathrm{CV}$ for the empirical chlorophyll data is high.

We have also investigated if it would be possible to test these model predictions of cyanobacteria against empirical data on cyanobacteria. The basic idea was to use information accessible from SMHI (see SMHI website), but that turned out to be very difficult for several reasons. The satellite images only give qualitative (not quantitative) information related to non specified algal blooms in the uppermost water layer at defined hours and the results depend very much on the cloudiness. Our model predictions concern the inventory of total cyanobacteria in the entire surface-water layer ( 0 to $44 \mathrm{~m}$ ) in the entire Baltic Proper on a monthly basis, and to transform the information conveyed by the satellite images has been beyond the possibilities of this work.

\section{The Fraction of N-Fixing Cyanobacteria}

All calculations so far are based on total concentrations of cyanobacteria $\left(\mathrm{CB}_{\text {tot }}\right)$ using the model in Fig. (3). The fraction of $\mathrm{N}$-fixing cyanobacteria $\left(\mathrm{CB}_{\mathrm{fix}}\right)$ is not identical to, but lower than, $\mathrm{CB}_{\text {tot }}$. We have estimated the ratio $\mathrm{CB}_{\mathrm{fix}} / \mathrm{CB}_{\text {tot }}$ using data from the Baltic Proper. The data comes from two monitoring stations, one outside the Askö research station (B1) and one at the Landsort deep (BY31). We have accessed the data at, http://www2.ecology.su.se/dbbm/JS.html.

Cyanobacteria from the order Nostocales can fix nitrogen in heterocysts. Nitrogen fixation is rather energy consuming, with each heterocyst requires 12 to 20 photosynthetic cells to provide the necessary energy supply [47].
Table 7. Compilation of Calculated Annual Maximum Potential Nitrogen Fixation in the Baltic Proper Between 1997 and 2005. Note that the Results from 2005 are Based on Interpolated Data for the Missing Months

\begin{tabular}{|c|c|}
\hline Year & N-Fix $(t / y r, \max )$. \\
\hline 1997 & 58303 \\
\hline 1998 & 70960 \\
\hline 1999 & 60443 \\
\hline 2000 & 116916 \\
\hline 2001 & 45181 \\
\hline 2002 & 131898 \\
\hline 2003 & 73642 \\
\hline 2004 & 254977 \\
\hline 2005 & 908087 \\
\hline Min & 45181 \\
\hline Max & 908087 \\
\hline Mean & 191156 \\
\hline Median & 73642 \\
\hline SD & 276448 \\
\hline CV & 1.45 \\
\hline $\mathbf{n}$ & 9 \\
\hline
\end{tabular}

Recent studies indicate that other primary producers (non-heterocystous cyanobacteria) smaller than $10 \mu \mathrm{m}$ may contribute considerably to nitrogen of the total $\mathrm{N}$-fixation in 
the Baltic Proper may be fixation [6]; measurements indicated that up to $43 \%$ done by these organisms, while not contributing much to total biomass.

Table 8. Compilation of Statistical Information TN/TP in the Surface-Water Layer of the Baltic Proper Using Data from 1990 to 2005

\begin{tabular}{|c|c|c|c|c|}
\hline & All & $\begin{array}{c}\text { Temp } \\
\mathbf{1 5}^{\circ} \mathbf{C}\end{array}$ & $\begin{array}{c}\text { Depth } \\
<\mathbf{2 0} \mathbf{~ m}\end{array}$ & $\begin{array}{c}\text { TP } \\
\mathbf{1 0} \mathbf{\mu g} / \mathbf{l}\end{array}$ \\
\hline \hline Min. & 1.05 & 1.74 & 1.74 & 1.74 \\
\hline Max. & 171 & 76.9 & 76.9 & 59.4 \\
\hline Mean & 16.5 & 20.1 & 20.4 & 18.7 \\
\hline Median & 15.2 & 19.5 & 19.8 & 18.8 \\
\hline SD & 8.1 & 9.2 & 9.2 & 7.4 \\
\hline CV & 0.49 & 0.46 & 0.45 & 0.40 \\
\hline $\mathrm{n}$ & 24048 & 3001 & 2880 & 2577 \\
\hline$\%<7.2$ & 7.0 & 6.5 & 6.0 & 6.6 \\
\hline$\%<15$ & 49.1 & 28.8 & 27.5 & 30.7 \\
\hline
\end{tabular}

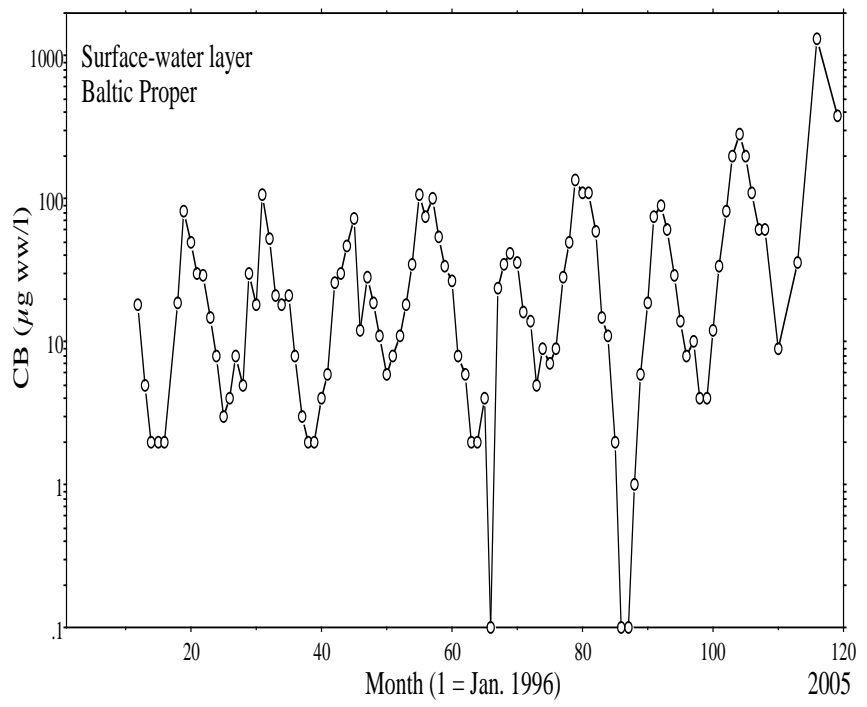

Fig. (5). Modelled concentrations of total cyanobacteria ( $\mu \mathrm{g} w w / 1$; $\mathrm{ww}=$ wet weight) in the surface-water layer of the Baltic Proper 1996 to 2005.

Because heterocyst-forming species of cyanobacteria do not always fix nitrogen and because small non-heterocystous cyanobacteria may contribute to $\mathrm{N}$-fixation, it is complicated to find a reliable value of $\mathrm{CB}_{\mathrm{fix}} / \mathrm{CB}_{\text {tot }}$. Further complicating matters include the high inherent $\mathrm{CV}$ for cyanobacteria and the fact that reliable data for the entire surface-water layer for longer periods of time from the Baltic Proper (or from most systems) are scarce. In this estimation of $\mathrm{CB}_{\mathrm{fix}} / \mathrm{CB}_{\mathrm{tot}}$, only the heterocyst-forming species have been considered. An average ratio of 0.85 was calculated from all 580 values (see Table 9).

The mean and median values when the water temperature is higher than $15^{\circ} \mathrm{C}$ (the threshold temperature for cyanobacteria) are between 0.84 and 0.97 , respectively. The actual $\mathrm{N}$ fixation may, however, be close to the modelled maximum values since $\mathrm{N}$-fixation from "small organisms" is not included in this ratio.

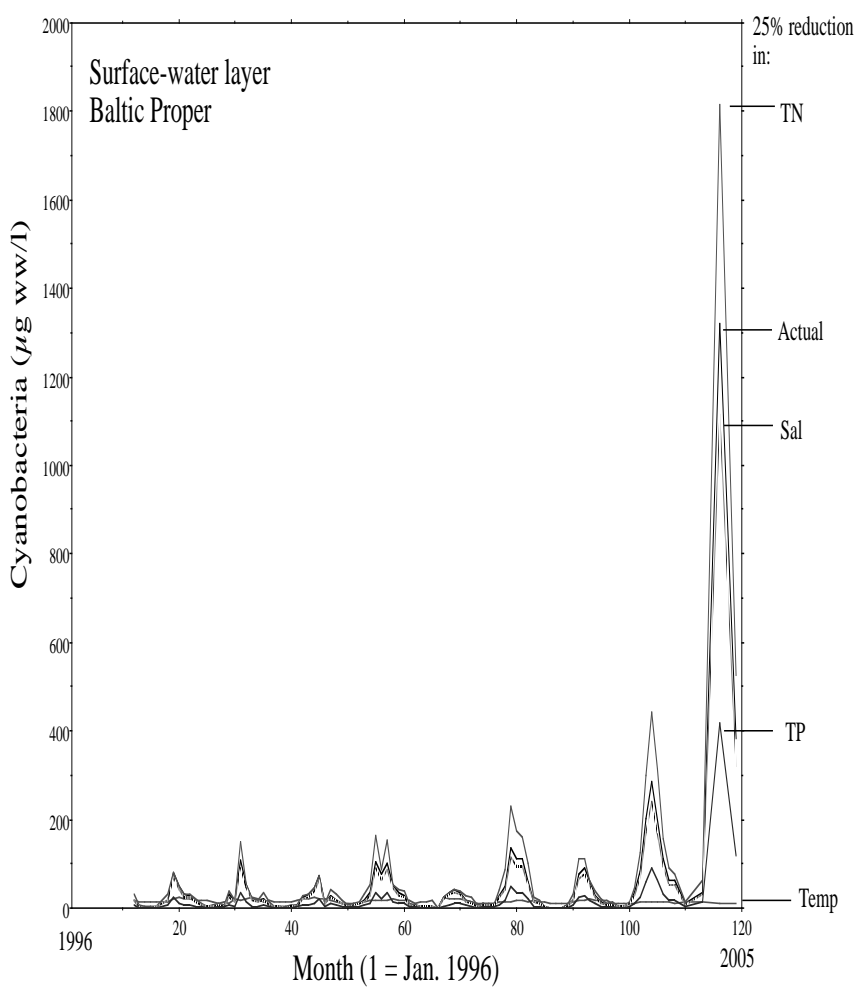

Fig. (6). Simulations to illustrate how $25 \%$ reductions in TN, TP, water temperature and salinity (Sal) would likely influence the concentrations of cyanobacteria in the surface-water layer of the Baltic Proper using data from 1996 to 2005. The curve marked "Actual" is based on empirical data from the given period.

[10] calculated $\mathrm{CB}_{\mathrm{fix}} / \mathrm{CB}_{\text {tot }}$ using lake data from [9], deriving a value of 0.33 , which is considerably lower than these results for the Baltic Proper.

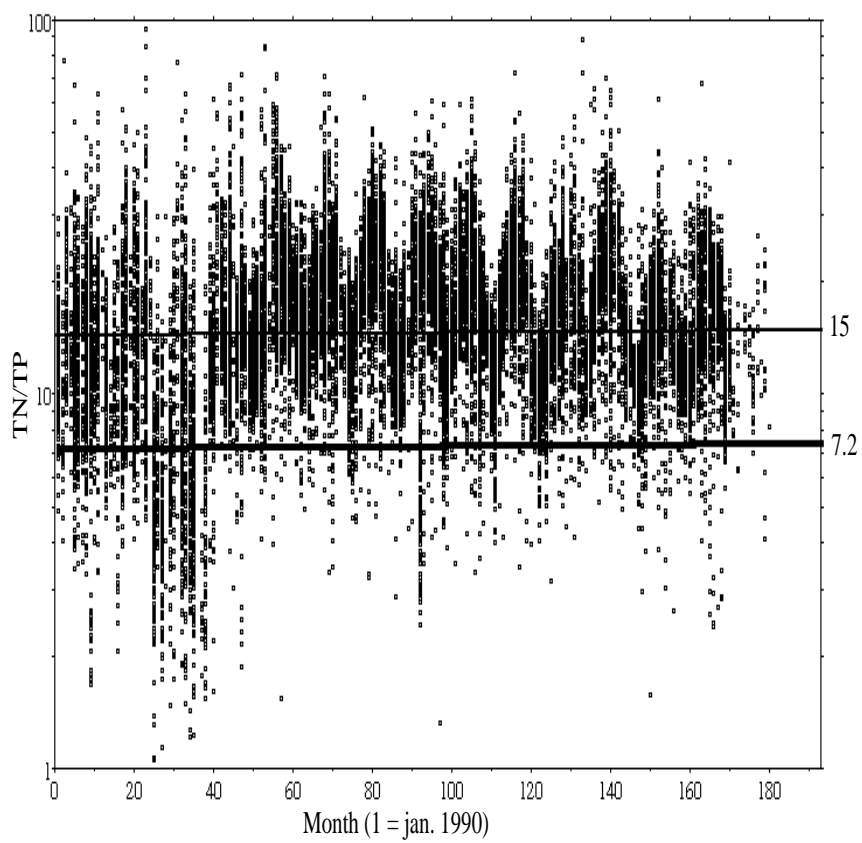

Fig. (7). TN/TP from all $(n=24048)$ surface-water samples in the Baltic Proper from 1990 to 2005. 


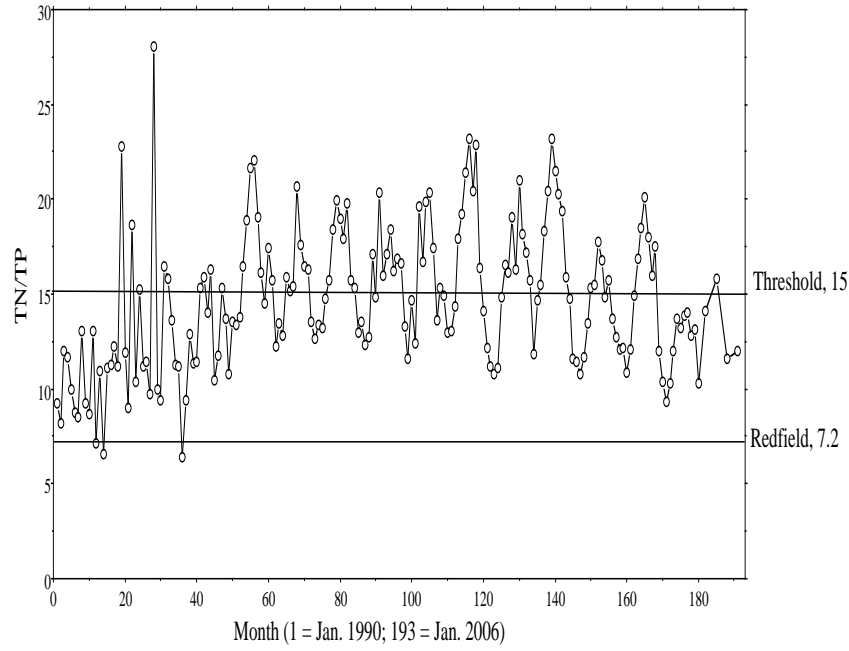

Fig. (8). Variations in median monthly TN/TP in the surface-water layer of the Baltic Proper from 1990 to 2005 in relation to the Redfield ratio of 7.2 and the threshold ratio of 15 (see text).

The mean compositions of cyanobacteria species or genus at the two monitoring stations in the Baltic Proper in situations with water temperatures higher than $15^{\circ} \mathrm{C}$ are given in Fig. (11). This diagram is included here so that these results from the Baltic Proper may be translated to other systems where different cyanobacteria with other $\mathrm{CB}_{\text {fix }} / \mathrm{CB}_{\text {tot }}$-ratio may prevail. The two nitrogen fixing species Aphanizomenon sp. and Nodularia spumigena are dominant, with $80 \%$ of the biomass. Then follow Cyandictyon spp., Pseudanabaena limnetica, Anabaena spp. and Anabaena lemmermannii with a few percent each. The remaining species contribute, on average, less than $1 \%$ of the biomass of cyanobacteria.

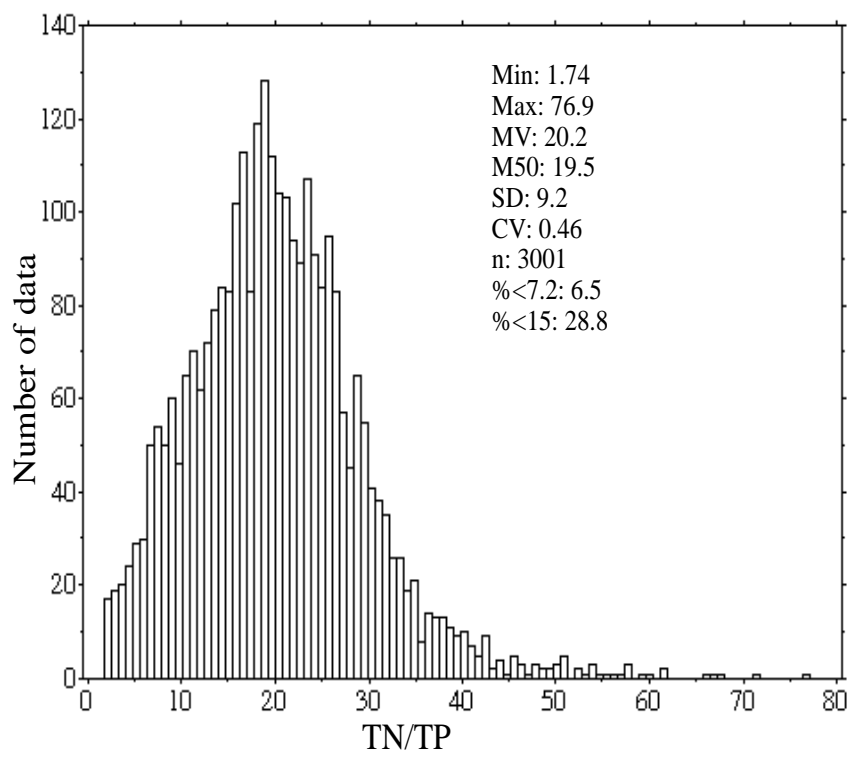

Fig. (9). Frequency distribution for TN/TP for all samples with temperatures higher than $15^{\circ} \mathrm{C}$ during 1990 to 2005 in the surfacewater layer of the Baltic Proper. $6.5 \%$ of the data have TN/TP < $7.2 ; 28.8 \%$ of the data ratios $<15$.

\section{CONCLUDING COMMENTS}

The empirically-based approach to predict total nitrogen fixation used in this work (from [10]) is general and could be used for other aquatic systems in a wide salinity range. It is

Table 9. The Ratio Between the Volume of Nitrogen Fixation Cyanobacteria to the Total Volume of Cyanobacteria from Two Monitoring Stations in the Baltic Proper, Askö (Data from 1983 to 2005) and the Landsort Deep (Data from 1990 to 2005). MV = Mean Value for All Data; $n=$ Number of Data. Temperature Data (T) from Askö from 1992 to 2004 and Landsort Deep from 1990 to 2004 at 0 to $20 \mathrm{~m}$ Depth

\begin{tabular}{|c|c|c|c|c|c|c|}
\hline \multirow{2}{*}{ Month } & \multicolumn{3}{|c|}{ Askö } & \multicolumn{3}{|c|}{ Landsort Deep } \\
\hline & $\mathbf{T}\left({ }^{\circ} \mathbf{C}\right)$ & $\mathbf{n}$ & $\mathbf{C B}_{\text {fix }} / \mathbf{C B}_{\text {tot }}$ & $\mathbf{T}\left({ }^{\circ} \mathbf{C}\right)$ & $\mathbf{n}$ & $\mathbf{C B}_{\text {fix }} / \mathbf{C B}_{\text {tot }}$ \\
\hline 1 & 1.6 & 10 & 0.50 & 3.0 & 11 & 0.79 \\
\hline 2 & 0.8 & 10 & 0.68 & 1.9 & 8 & 0.83 \\
\hline 3 & 1.2 & 11 & 0.93 & 1.7 & 23 & 0.88 \\
\hline 4 & 2.7 & 16 & 0.87 & 2.7 & 38 & 0.90 \\
\hline 5 & 6.5 & 21 & 0.94 & 5.7 & 28 & 0.93 \\
\hline 6 & 10.9 & 38 & 0.96 & 9.7 & 32 & 0.97 \\
\hline 7 & 13.6 & 53 & 0.96 & 13.5 & 34 & 0.87 \\
\hline 8 & 15.3 & 52 & 0.87 & 15.5 & 34 & 0.82 \\
\hline 9 & 12.8 & 37 & 0.79 & 13.5 & 25 & 0.85 \\
\hline 10 & 9.3 & 29 & 0.73 & 10.3 & 21 & 0.69 \\
\hline 11 & 6.4 & 13 & 0.91 & 7.2 & 14 & 0.51 \\
\hline 12 & 4.0 & 10 & 0.69 & 5.4 & 11 & 0.74 \\
\hline Median for $\mathrm{T}>15^{\circ} \mathrm{C}$ & 17.2 & 30 & 0.97 & 16.8 & 34 & 0.91 \\
\hline Mean for $\mathrm{T}>15^{\circ} \mathrm{C}$ & 17.2 & 30 & 0.92 & 16.6 & 34 & 0.84 \\
\hline Mean for all data & 7.6 & 301 & 0.86 & 7.8 & 279 & 0.84 \\
\hline
\end{tabular}


meant to give seasonal or monthly data for the surface-water layer. When tested using empirical data for the Baltic Proper, there was reasonably good overall correspondence between the estimates using this model and other approaches. For the future, it would be important to have better data on the fraction of nitrogen fixing cyanobacteria not just in the Baltic Proper but more generally, so that a general algorithm could be derived for this important ecosystem characteristic.

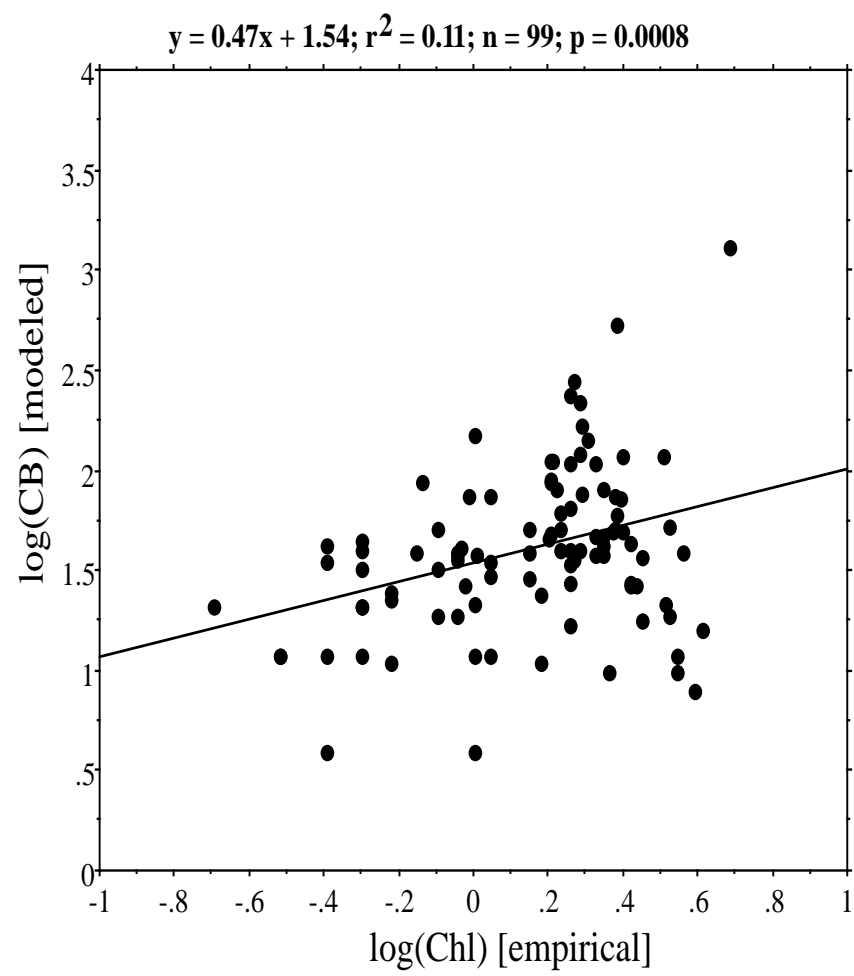

Fig. (10). The relationship between empirical median monthly concentrations of chlorophyll-a $(\mu \mathrm{g} / \mathrm{l})$ and modelled concentrations of cyanobacteria $(\mu \mathrm{g} \mathrm{ww} / \mathrm{l})$ using data from 1997 to 2005 for the surface-water layer of the Baltic Proper.

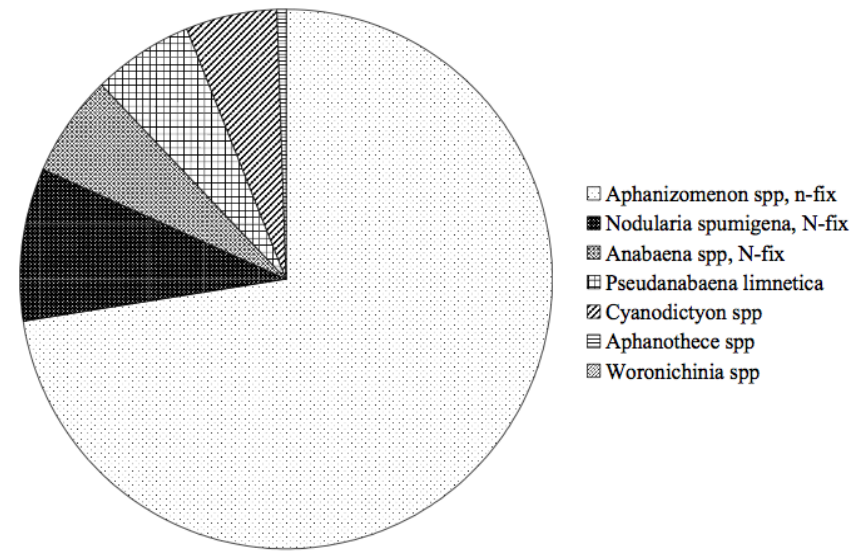

Fig. (11). Average composition of Cyanobacteria at water temperatures higher than $15^{\circ} \mathrm{C}$ at Askö (station B1) using data from 30 days sampled between 1992 to 2004 and at the Landsort deep, (station BY31) using data from 34 days collected between 1990 to 2004.

\section{REFERENCES}

[1] Savchuk O, Wulff F. Modelling regional and large-scale response of Baltic Sea ecosystems to nutrient load reductions. Hydrobiologia 1999; 393: 35-43.
[2] Tyrrell $\mathrm{T}$. The relative influences of nitrogen and phosphorus on oceanic primary production. Nature 1999; 400: 525-31.

[3] Wasmund N. Occurrence of cyanobacteria blooms in the Baltic Sea in relation to environmental conditions. Int Revue ges Hydrobiol 1997; 82: 169-84.

[4] Rahm L, Jönsson A, Wulff F. Nitrogen fixation in the Baltic proper: an empirical study. J Mar Syst 2000; 25: 239-48.

[5] Larsson U, Hajdu S, Walve J, Elmgren R. Baltic Sea nitrogen fixation estimated from the summer increase in the upper mixed layer. Limnol Oceanogr 2001; 46: 811-20.

[6] Wasmund N, Voss M, ad Lochte K. Evidence of nitrogen fixation by non-heterocystous cyanobacteria in the Baltic Sea and recalculation of a budget of nitrogen fixation. Mar Ecol Prog Ser 2001; 214: 1-14.

[7] Wasmund N, Nausch G, Schneider B, Nagel K, Voss M. Comparison of nitrogen fixation rates determined with different methods: a study in the Baltic Proper. Mar Ecol Prog Ser 2005; 297: 23-31.

[8] OECD. Eutrophication of waters. Monitoring, assessment and control. OECD, Paris 1982; p. 154.

[9] Smith VH. Predictive models for the biomass of blue-green algae in lakes. Water Resour Bull 1985; 21: 433-9.

[10] Håkanson L, Bryhn AC, Hytteborn JA. On the issue of limiting nutrient and predictions of bluegreen algae in aquatic systems. Sci Total Environ 2007; 379: 89-108.

[11] Melvasalo T, Niemi A, Niemitö L, Rinne I. On the importance of nitrogen fixation in the Baltic Sea ecosystem. Symposium on Ecological Investigations of the Baltic Sea Environment, Riga 16-19 March 1983; pp. 176-89.

[12] Leppänen JM, Niemi A, Rinne I. Nitrogen fixation of cyanobacteria (blue-green algae) and nitrogen cycle of the Baltic Sea. Symposis 1988; 6: 181-94.

[13] Rönner U. Nitrogen transformations in the Baltic proper: denitrification counteracts eutrophication, Ambio 1985; 14: 134-8.

[14] Hübel H, Hübel M. Blaualgen-Wasserblüten in der Ostsee: Ursachen-Ausmass-Folgen. Dtsch Hydrogr Z (Suppl) 1995; 2:151-8.

[15] Redfield AC, Ketchum BH, Richards FA. In: Hill N, Ed. The influence of organisms on the composition of sea-water. The Sea 2. Interscience, New York 1963; pp. 26-77.

[16] Hassett RP, Cardinale B, Stabler LB, Elser JJ. Ecological stoichiometry of $\mathrm{N}$ and $\mathrm{P}$ in pelagic ecosystems: comparison of lakes and oceans with emphasis on the zooplankton-phytoplankton interaction. Limnol Oceanogr 1997; 42: 648-62.

[17] Vidal M, Duarte CM, Agusti S. Dissolved organic nitrogen and phosphorus pools and fluxes in the central atlantic ocean. Limnol Oceanogr 1999; 44: 106-15.

[18] Dodds WK. Misuse of inorganic N and soluble reactive P concentrations to indicate nutrient status of surface waters. JNABS 2003 22: $171-81$.

[19] Dillon PJ, Rigler FH. The phosphorus-chlorophyll relationship in lakes. Limnol Oceanogr 1974; 19: 767-73.

[20] Meeuwig JJ, Kauppila P, Pitkänen H. Predicting coastal eutrophication in the Baltic: a limnological approach. Can J Fish Aquat Sci 2000; 57: 844-55.

[21] Håkanson L. Suspended particulate matter in lakes, rivers and marine systems. The Blackburn Press, New Jersey 2006; p. 331.

[22] Floderus S. The effect of sediment resuspension on nitrogen cycling in the Kattegat-variability in organic matter transport. UNGI Report 71, Dr. thesis, Uppsala University, Sweden 1989.

[23] Wulff F, Rahm L, Larsson P, Eds. A systems analysis of the Baltic Sea. Springer-Verlag, Berlin, Ecological Studies 2001; Vol. 148: p. 455.

[24] Ryther JH, Dunstan WM. Nitrogen, phosphorus, and eutrophication in the coastal marine environment. Science 1971; 171: 1008-13.

[25] Guildford SJ, Hecky RE. Total nitrogen, total phosphorus, and nutrient limitation in lakes and oceans: Is there a common relationship? Limnol Oceanogr 2000; 45: 1213-23.

[26] Wetzel RG. Limnology. Academic Press, London 2001; p. 1006.

[27] Moisander PH, McClinton E, Paerl HW. Salinity effects on growth, photosynthetic parameters and nitrogenase activity in estuarine planktonic cyanobacteria, Microbila. Ecology 2002; 43: 432-42.

[28] Havens KE, James RT, East TL, Smith VH. N:P ratios, light limitation, and cyanobacterial dominance in a subtropical lake impacted by non-point source nutrient pollution. Environ Pollut 2003; 122: 379-90.

[29] Reynolds CS, Walsby AE. Water-blooms. Biol Rev 1975; 50: 437 81 . 
[30] Edler Å. Blue-green algal blooms and N:P ratio in the Baltic Sea. Acta Bot Fennica 1979; 110: 57-61.

[31] Konopka A, Brock TD. Effect of temperature on blue-green algae (Cyanobacteria) in Lake Mendota. Appl Environ Microbiol 1978; 36: $572-6$

[32] Lehtimäki J, Sivonen K, Luukainen R, Niemelä SI. The effects of incubation time, temperature, light, salinity, and phosphorus on growth and hepatotoxin production by Nodularia strains. Arch Hydrobiol 1994; 130: 269-82.

[33] Lehtimäki J, Moisander P, Sivonen K, Kononen K. Growth, nitrogen fixation, and Nodularin production by two Baltic Sea Cyanbacteria. Appl Environ Microbiol 1997; 63: 1647-56.

[34] McQueen DJ, Lean DRS. Influence of water temperature and nitrogen to phosphorus ratios on the dominance of blue-green algae in Lake St. George, Ontario. Can J Fish Aquat 1987; 44: 598-604.

[35] Marumo R, Asaoka O. Distribution of pelagic blue-green algae in the Northen Pacific ocean. J Oceanogr Soc Jpn 1974; 30: 77-85.

[36] Lukatelich RJ, McComb AJ. Nutrient levels and the development of diatoms and blue-green algal blooms in a shallow Australian estuary. J Plankton Res 1986; 8: 597-618.

[37] Robarts RD, Zohary T. Temperature effects on phytosynthetic capacity, respiration, and growth rates of bloom-forming cyanobacteria. NZ J Mar Freshwater Res 1987; 21: 391-9.

[38] Howarth RW, Marino R, Cole JJ. Nitrogen fixation in freshwater, estuarine, and marine ecosystems 2 . Biogeochemical controls. Limnol Oceanogr 1988; 33: 688-701.

[39] Howarth RW, Marino R, Lane J, Cole JJ. Nitrogen fixation in freshwater, estuarine, and marine ecosystems. 1. Rates and importance. Limnol Oceanogr 1988; 33: 669-87.

[40] Marino R, Chan F, Howarth RW, Pace ML, Likens GE. Ecological constraints on planktonic nitrogen fixation in saline estuaries. I. Nutrient and trophic controls. Mar Ecol Prog Ser 2006; 309: 25-39.

[41] Sellner KG. Physiology, ecology and toxic properties of marine cyanobacteria blooms. Limnol Oceanogr 1997; 42: 1089-104.

[42] Zehr JP, Jenkins BD, Short SM, Steward GF. Nitrogenase gene diversity and microbial community structure: a cross-system comparison. Environ Microbiol 2003; 5: 539-54.

[43] HELCOM. Baltic Sea Environment Proceedings No. 100 from the HELCOM website 2000.
[44] Pienitz R, Smol JP, Lean DRS. Physical and chemical limnology of 59 lakes located between the southern yukon and the tuktoyaktuk peninsula, Northwest Territories (Canada). Can J Fish Aquat Sci 1997; 54: 330-46.

[45] Håkanson L, Malmaeus JM, Bodemar U, Gerhardt V. Coefficients of variation for chlorophyll, green algae, diatoms, cryptophytes and blue-greens in rivers as a basis for predictive modelling and aquatic management. Ecol Modell 2003; 169: 179-96.

[46] Håkanson L. Physical geography of the Baltic. The Baltic University. Session 1. Uppsala University 1991.

[47] Vitousek PM, Cassman K, Cleveland C, et al. Towards an ecological understanding of biological nitrogen fixation. Biochemistry 2002; 57/58: 1-45.

[48] Håkanson L, Lindgren D. On regime shifts and budgets for nutrients in the open Baltic Proper-evaluations based on extensive data between 1974 and 2005. J Coast Res 2008; 24: 246-60.

[49] SNV. Eutrophication of land, freshwater and the Sea (in Swedish, Eutrofiering av mark, sötvatten och hav). Swedish Environmental Protection Agency, Report 4134, Stockholm 1993; p. 199.

[50] Håkanson L, Boulion V. The Lake Foodweb-modelling predation and abiotic/biotic interactions. Backhuys Publishers, Leiden 2002; p. 344 .

[51] Golubkov MS, Golubkov SM, Gubelit YI, Litvinchuk LF. Primary production and composition of phytoplankton assemblages in hypersaline lakes of Crimea peninsula. Proc Zool Inst Russ Acad Sci 2006.

[52] Wallin M, Håkanson L, Persson J. Load models for nutrients in coastal areas, especially from fish farms (in Swedish with English summary). Nordiska ministerrådet, Copenhagen 1992; 502: p. 207.

[53] Petersen JK, Hansen JW, Laursen MB, Conley D. Regime shift in a marine coastal ecosystem. Manuscript, National Environmental Research Institute and County of Ringkjøbing 2006.

[54] Bryhn AC, Håkanson L, Eklund JM. Variabilities and uncertainties in key coastal water variables as a basis for understanding changes and obtaining predictice power in modelling. J Coast Res 2008; in press.

[55] Håkanson L, Bryhn AC. Eutrophication in the Baltic Sea-present situation, nutrient transport processes, remedial strategies. Springer Verlag, Berlin, Heidelberg 2008; p. 264. 